\title{
THE SOCIAL AND MORAL ESSENCE OF THE SPIRITUAL HERITAGE OF SADRIDDIN SALIM BUKHARI
}

\author{
Kuchkarova Shakhodat Ruzievna \\ Senior Lecturer, Department of Foreign Languages, \\ Bukhara engineering - technological Institute, Bukhara, Uzbekistan
}

\begin{abstract}
Uzbekistan is one of the world's leading countries in terms of richness, antiquity and uniqueness of its cultural and spiritual heritage. It is the duty of all of us to preserve this priceless wealth like the apple of an eye, to promote it on a large scale. This article discusses the social and moral essence of the rich spiritual heritage of Sadriddin Salim Bukhari, the true son of our country, who left an indelible mark on our history.
\end{abstract}

Keywords: S.S. Bukhari's heritage, cultural and spiritual heritage, scientific and philosophical heritage.

\section{Introduction}

In order to be proud of our land, first of all, we can promote it to the wider world only if we know its rich art, history, sacred monuments and masterpieces. Knowledge of history and identity is achieved through spreading.

Indeed, today Uzbekistan amazes the whole world with its skyscrapers, centuries-old luxury buildings, holy and sacred shrines. Today, at the initiative of President Shavkat Mirziyoyev, the beautification of sacred places and shrines in the regions of the country is in full swing. Especially the work of the "Yetti Pir" in Bukhara? Every time I go to Bukhara, I pray to Allah that those who do this will be supported by the pure souls of these saints. You will not find in any country the magnificent mosques built in the holy shrines and the noble ideas written on the roofs of madrassas with high calligraphy.

\section{Main part}

Our ancestors used colors in buildings that do not fade or change - they remain the same for centuries. To this day, scientists are puzzled by the inability to determine what these colorful inks are made of. Look, in the past we were a nation with a high level of intelligence and potential in terms of paint creation as well. It would not be wrong to say that Sadriddin Salim Bukhari's scientific and philosophical heritage made him love the land of Bukhara even more. It is still rare to find a writer who described Bukhara as Sadriddin Salim Bukhari and wrote about its history. The poet truly loved his country, and in his poems he struggled with the towers of this land, the "Labi Hovuz", as well as what he considered dear, and warned the next generation to preserve it, show it to the whole world. Dear saints, thinkers from our country, along with exemplary ways of life, have left a rich spiritual heritage. There is still a lot of work to be done to study them and to promote their content and ideas. In this regard, a number of educational meetings are being held.

This imposes a responsibility on all people, as the saints who lived on our land are perfect human beings. The study and analysis of the outstanding scientists of our people, their worthy contribution to the development of world science on the basis of the idea of national revival in the new Uzbekistan is one of the current issues. In particular, in the year when Bukhara was recognized as the capital of Islamic culture, the great representative of the Bukhara School of Philosophy Sadriddin Salim Bukhari's scientific and philosophical heritage is also a fundamental work in the field of Islamic philosophy. Bukhara has always been a center of knowledge and enlightenment. Great scholars such as Imam Bukhari, Abdurahman Jami, Abdukholiq Gijduvani, Ibn Sino, Ahmad Donish, Sadriddan Aini, Ibrahim Muminov grew up on this land. The services of Sadriddin Salim Bukhari in the study and promotion of this spiritual heritage are invaluable. [2]

One of the main tasks of today's scientific community is to widely promote the life and work of scientists who grew up in our country in the speeches of the President on the study of the heritage of Eastern scholars. The great poet, translator and philosopher Sadriddin Salim Bukhari is a humble and selfless man who continued the good deeds of our great ancestors. Sadriddin Salim Bukhari is the author of about a dozen pamphlets about the saints of Bukhara, especially the "Yetti Pir" of Bukhara, a number of poetry collections, and wrote a script for a series of videos about our great compatriot Imam al-Bukhari. Translated Goethe's epic "West and East" from German into Uzbek and presented it to students After the independence of our holy and blessed country Uzbekistan, science, literature and art began to develop in a truly new way. The awakened spiritual power of our people, the works of art that express the breath of the new age have multiplied, a number of artists have grown up and entered the field of literature. Sadriddin Salim Bukhari is one of the poets who has such a unique voice, the potential of the country, the ideas of freedom and liberty.

On August 30, 2010 in Bukhara was held the opening ceremony of the complex "Ancient and eternal Bukhara". First president Islam Karimov spoke about those who had contributed to the construction of this huge complex, including the name of the country's selfless son Sadriddin Salim Bukhari. In fact, this was the highest appreciation given to the life and work of Sadriddin Salim. Sadriddin Salim Bukhari was also awarded with the "Order of Selfless Service" and the "Order of Labor Glory". He can truly be called a selfless worker. 
Sadriddin Salimov was born on September 16, 1946 in the Chopboz guzar in the city of Bukhara. He graduated from the German language faculty of Bukhara Pedagogical Institute (1972). Sadriddin Salim Bukhari is not only a noble city poet, but also a noble poet. «Oqqushim», «Erka qushim» (1979), «Yoruglik odami» (1983), «Rumolcha» (1988), «Buhoroga Buhoro keldi» (1999), «Durdonalar» (2005) such poetry collections were published. In his verses, which are simple and full of meaning and sincerity, the breath of the ancient Bukhara, in which he was born and grew up, breathes. [3]

He also wrote several historical and enlightenment books («Bahouddin Naqshband yoki etti pir», 1993; «Uch avliyo», 2000; «Hazrat Abu Kafs Kabir», 2006; «Ikki yuz etmish etti pir», 2006; «Hazrat Bahouddin Naqshband», 2006; «Hazrat Ka'bul Axbor Valiy», 2007 and others).

Sadriddin Salim Bukhari is a poet, a historian and an enlightened scholar, who continued the tradition of classical Eastern literature on the one hand. His books and articles on the history of Bukhara and Bukhara scholars are moving from hand to hand, from heart to heart. He is also a mystic. His treatises on the theory and practice of mystical and mystical literature are well known today not only by our people, but also by the German, English and French masses. Another aspect of his scientific and creative activity is complemented by the masterful translation of the teacher. Today our people read with great pleasure of works of great German poet and thinker I.V. Goethe's worldfamous "West-East Divan", Abdulhaliq Gijduvani, Khoja Ali Romitani, Said Amir Kulol, Bahauddin Naqshband, Muhammad Baqir, and other scholars. [1]

It's not all that, he was a fiery preacher. While our people make a worthy contribution to the spiritual and enlightenment education of the younger generation, he taught the subject of "Oriental Pedagogy" at the Bukhara Regional Institute of Teacher Training. Each of these lessons, if recorded, was worth calling a separate pamphlet. The rich heritage left to us by Sadriddin Salim Bukhari has a unique historical, enlightenment and educational significance. His pamphlets, first of all, serve to a deeper understanding of the essence of national and spiritual values, doctrines and views, which are the product of deep thinking of our great ancestors.

Secondly, in connection with the radical change in the attitude to the past during the independence period, the author believes that the beliefs of our ancestors, historical memory, national values were restored, sacred sites were prosperous, and when and by whom and under what conditions such meritorious deeds were carried out. And the fact that these things have been further enhanced by the enlightenment of their pamphlets.

Thirdly, in the author's books, the names of some cities, districts, villages or streets in Bukhara region are directly or indirectly related to the mentioned historical figures, which contain information about the history and etymology of toponymic objects. This is an important source on the basis of compiling the "Dictionary of place names of Bukhara region" and acquainting the population with the history of the place of residence.

Fourth, another important feature of the author's historical treatises is that they are written on the basis of a reliable source and logical evidence, in contrast to the legends narrated orally among the people. The author expresses his attitude to the existing errors and omissions in the sources and legends about the life and work of our great ancestors, and corrects them on the basis of accurate information.

Fifth, the author's books are important not only from a historical and educational point of view, but also from an educational point of view. They glorify the virtues of the possessors of great intelligence and deep thinking in the field of generosity and kindness, patience, justice, faith, knowledge and enlightenment, teacher-student relations. The rare qualities of our great ancestors awaken in the heart of the reader a sense of pride in the great past of our ancestors, and their example inspires them to become worthy heirs, to continue their glorious path, to perfection, to great goals.

\section{Conclusion}

As a conclusion, we can say Sadriddin Salim Bukhari was not only a great poet, a skilled translator, and did not claim to be a scholar, but he was in fact an intelligent enlightened scholar. Sadriddin Salim Bukhari studied the life and legacy of "Yetti Pir", who grew up in the land of Bukhara from the first years of independence - a series of scholars related to the education of a person with invaluable knowledge. Another important aspect is that patriotism is evident in each of his works, and this feeling inspires you to do the same. Every inch of ancient Bukhara is sacred, and the unique architectural monuments erected there are sacred. Buildings embody the affection of the ancestors who built it.

\section{References}

1. Bukhori S.S. Sacred shrines of Bukhara, "Durdona" print house, 2012. Bukhara.

2. Bukhori S.S. Bakhouddin Naqshband or Yetti Pir, Yozuvchi print house, University of Michigan. 1993

3. https://ziyouz.uz/ozbek-ziyolilari/sadriddin-salim-buxori-1946-2010/ 